\title{
Demand Forecasting model based on artificial neural networks for Passenger Transportation Projects
}

\author{
Modelo de previsão de demanda baseado em redes \\ neurais artificiais para projetos de transporte de passageiros
}

\author{
Vagner Sanches Vasconcelos [a] [D], Filipe Quevedo-Silva [b] [D] \\ Ricardo Leonardo Rovai [a] [D
}

[a] Universidade Nove de Julho (UNINOVE), São Paulo, SP, Brasil

[b] Universidade Federal de Mato Grosso do Sul, (UFMS), Campo Grande, MS, Brasil

How to cite: Vasconcelos, V. S., Quevedo-Silva, F., \& Rovai, R. L. (2021). Demand Forecasting model based on artificial networks for Passenger Transportation Projects. urbe. Revista Brasileira de Gestão Urbana, v. 13, e20200160.

https://doi.org/10.1590/2175-3369.013.e20200160

\section{Abstract}

Whereas passenger demand is one of the main risks in passenger transport infrastructure projects on track, this paper aims to propose a demand forecasting model based on artificial neural networks (ANN) in order to contribute to the project management still in its early planning stages. For this, the design of ex post facto type was used in a descriptive research with quantitative approach, where the research group was composed by subway and train stations in the metropolitan region of São Paulo-Brazil. In total, 12 ANN were proposed architectures with 15 different configurations, totaling 180 training processes, testing and validation. For each architecture has been identified the lowest mean square error percentage obtained; and the best architecture, with a hidden layer, was performed relevance analysis by Garson method, the model 4 input variables: the population; the school enrolment; the number of jobs; and per capita income. With the proposed model, one expects to contribute to the theory by adding to demand forecasting models using a robust methodology and, for managers, serve as a tool in studies of economic and financial viability of these projects, still in its planning phase anticipated as an investment decision-making tool.

Keywords: Project Management. Early Project Planning. Demand Forecasting. Artificial Neural Networks.

\section{Resumo}

Considerando que a demanda de passageiros é um dos principais riscos nos empreendimentos de infraestrutura de transporte de passageiros sobre trilhos, este trabalho objetiva propor um modelo de previsão de demanda, baseado em redes neurais artificiais, de forma a contribuir com a gestão de projetos ainda em sua fase de planejamento antecipado. Para isso, foi utilizado o delineamento do tipo expost facto, numa pesquisa do tipo descritiva com abordagem quantitativa, em que o grupo de investigação foi formado pelas estações de metrô e

VSV is mechanical engineer, Master in Project Management, e-mail: vsvasconcelos@gmail.com 
de trem da Região Metropolitana de São Paulo. Foram propostas 12 arquiteturas de RNA com 15 configurações diferentes, totalizando assim 180 processos de treinamento, teste e validação. Para cada uma das arquiteturas, foi identificado o menor erro médio quadrado percentual obtido; e para a melhor arquitetura, com uma camada oculta, foi realizada a análise de relevância, pelo método de Garson, das 4 variáveis de entrada do modelo: a população; o número de matrículas escolares; o número de empregos; e a renda per capita. Com o modelo proposto, espera-se contribuir à teoria ao somar aos modelos de previsão de demanda utilizando uma metodologia robusta e, para os gestores, servir como ferramenta de auxílio nos estudos de viabilidade econômicofinanceiro desses empreendimentos, ainda em sua fase de planejamento antecipado, como uma ferramenta de tomada de decisão de investimento.

Palavras-chave: Gestão de projetos. Planejamento antecipado de projeto. Previsão de demanda. Redes neurais artificiais.

\section{Introduction}

In a country of continental dimensions like Brazil, the transportation infrastructure is critical to the development and efficiency of the entire economy (Ghisolfi et al., 2019). Fedorenko (2019) lists the encouragement of the development and welfare of a society with the transport and logistics infrastructure projects, and these may contribute to the sustainable growth of cities and regions. In line with this idea, Campos (2013) cites the vision of urban sustainability of transport systems, where the supply of these should occur in a sustainable way, improving the quality of life. The lack of planning and prioritizing in public transport lead to urban chaos in transport, growth of the number of cars and increasing levels of congestion and pollution (Ghisolfi et al., 2019).

One way to decrease congestion is investment in transport infrastructure. However, with respect to passenger transportation infrastructure projects, Alvim, Bilt, and Darido (2010) state that the rate of construction is not meeting the demand, resulting in overcrowding in existing systems, and a significant increase in congestion levels in traffic main Brazilians metropolitan areas. Infrastructure projects, according to Brandão and Saraiva (2007), are strongly affected by political and regulatory considerations; this is due to the large amount of resources and maturation times, and yet to cover services considered essential to society.

Thus, for the private sector to invest in projects of this type, knowledge and risk mitigation are key. To Bonomi and Malvessi (2008), one of the main processes in the realization of a project is to know and measure their risks in order to quantify them, and establish mitigation instruments. One of the most used ways to analyse the investment decision is the methodology of discounted cash flow (DCF) (Graham \& Harvey, 2002). It is necessary, among other things, the calculation of operating income of the enterprise, which in the case of passenger transport infrastructure projects, depends directly on user demand and the price paid for the ticket; thus predicted passenger demand is crucial for making investment decisions.

As noted by Vasconcelos et al. (2019), passenger demand is one of the main risk factors in passenger transport infrastructure projects. According to Dreyer et al. (2018), the demand forecast is recognized by companies as an important planning tool, at all organizational levels, ranging from operational to strategic planning. Xu, Chan and Zhang (2019) and Flyvbjerg (2013) emphasizes the importance of passenger demand forecasting to project managers and decision makers, as it influences capital investment costs (CAPEX) and operation and maintenance (OPEX) and risks of Operating income of the enterprise, i.e. its cash flow; hence already in the early planning phase (Front-End Loading - FEL) it should be considered.

There are several demand forecasting techniques (Hassan, Mahmassani, \& Chen, 2020; van Engelen, Cats, Post, \& Aardal, 2018). Fouto, Angelo, Zwicker and Luppe (2011) state that they are complementary, and the areas of planning organizations merge different approaches in order to achieve the best results. However, among the various developed techniques, artificial neural networks (ANN) have been identified as efficient and being presented as alternative modelling in various areas of knowledge (Barua, Zou, \& Zhou, 2020). Comparing the ANN approach with other techniques of multivariate data analysis, Hair, Black, Babin 
and Anderson (2010) report that while the latter feature the problems in a mathematical approach, ANN using a learning structure where mistakes output feed back into the system to adjust it properly.

In the transportation planning area, a set of models typically used for demand prediction model is the Urban Transportation System Model (UTMS) (Laiza et al, 2008). This model uses as input variables: the Search Origin-Destination; socioeconomic data; and data of road systems to estimate passenger demand.

Therefore, seeking leverage the UTMS model, an adaptation by applying the input data of this model to a neural model in order to train it, test it and validate it. Thus, the purpose of this paper is to propose a demand forecasting model based on ANN, using input variables of the UTMS model for use in the study phase of Economic and Financial Feasibility passenger rail projects. This research continues the master's thesis of Vasconcelos (2015). The results obtained contribute to the theoretical body of project management to present a new forecasting model using ANN methodology and provides tools to estimate passenger demand in future passenger transport enterprises, allowing initial sensitivity economic and financial analysis of these projects.

\section{Background}

\section{Early project planning}

The activities of an organization can be divided into operations and projects; operations involving routine activities, such as production and services, since the projects are unique initiatives such as the launch of new products. The evaluation of a project success must be associated with its benefit to the organization over time. In a business perspective, expectations of success are still to be defined during its planning phase, and further, its effective success should be evaluated. The project team should address, even while running, the success of the project and the project outcome (product or service). In this scenario, the project manager has his expanded role, rising to account also for the successful outcome of the project to the company's business, as well as continuing with the responsibilities of project execution (Shenhar \& Dvir, 2010).

Sales and Junior (2011), said that obtaining an efficient plan for the development of a new product enables: i) execution with quality, since the whole development process is thoroughly analysed, impacting on reducing rework; ii) the prioritization of activities, since stocks are selected to add value to the product, thus avoiding spending misaligned projects with organizational strategy and that will not bring the expected return; iii) the execution of activities in parallel, since one can ensure that activities are carried out in parallel without losses / quality problems or rework; iv) the establishment of cross-functional teams, providing teamwork with professionals from various skills to achieve good results; v) the strong market orientation, focusing on understanding consumer needs and scope of the product by the demand, and hence its success; and vi) a focus on initial activities (front-end) product development, as it stimulates the preliminary investigation, the attention to the scope and minimizes changes in the course of the project that generate large costs.

This decision-making approach received the name of Stage-Gate ${ }^{\circledR}$ model. According to Cooper (2008), Stage-Gate ${ }^{\circledR}$ model is a conceptual and operational map for the launch of new product designs ideas. At the same time, it is a management model aimed at improving the efficiency and effectiveness of the process of development of these products.

Kerzner (2011) states that the Stage-Gate ${ }^{\circledR}$ process seems to have been replaced by phases of the project life cycle. However, the process continues to be used now internally within each stage of the lifecycle, as a decision-making tool. The advantage of this new approach is that while the life cycle phases are the same for all projects, the Stage-Gate ${ }^{\circ}$ process can be adapted to each project in order to facilitate decisionmaking and risk management. With this new use, the Stage-Gate ${ }^{\circledR}$ process becomes an integral part of project management, when it was previously used primarily in the development of new products. 
The mega-projects management methodology, shown in Figure 1, known as Front-End Loading (FEL), is another model based on decision gates: which according to Ribeiro do Valle, Soares and Santos (2013) it is used in mega-projects, where investments are of high value. Their use is intended to minimize the risks of investments in projects of this nature. Usually it is applied in industrial sectors such as mining, petrochemical, power and where the projects are of high complexity and excessive costs. Flyvbjerg, Bruzelius and Rothengatter (2003) reported examples of infrastructure megaprojects that have experienced high excess costs, identifying the main causes of this inadequate deliberation on risk and the lack of accountability in project decision-making process.

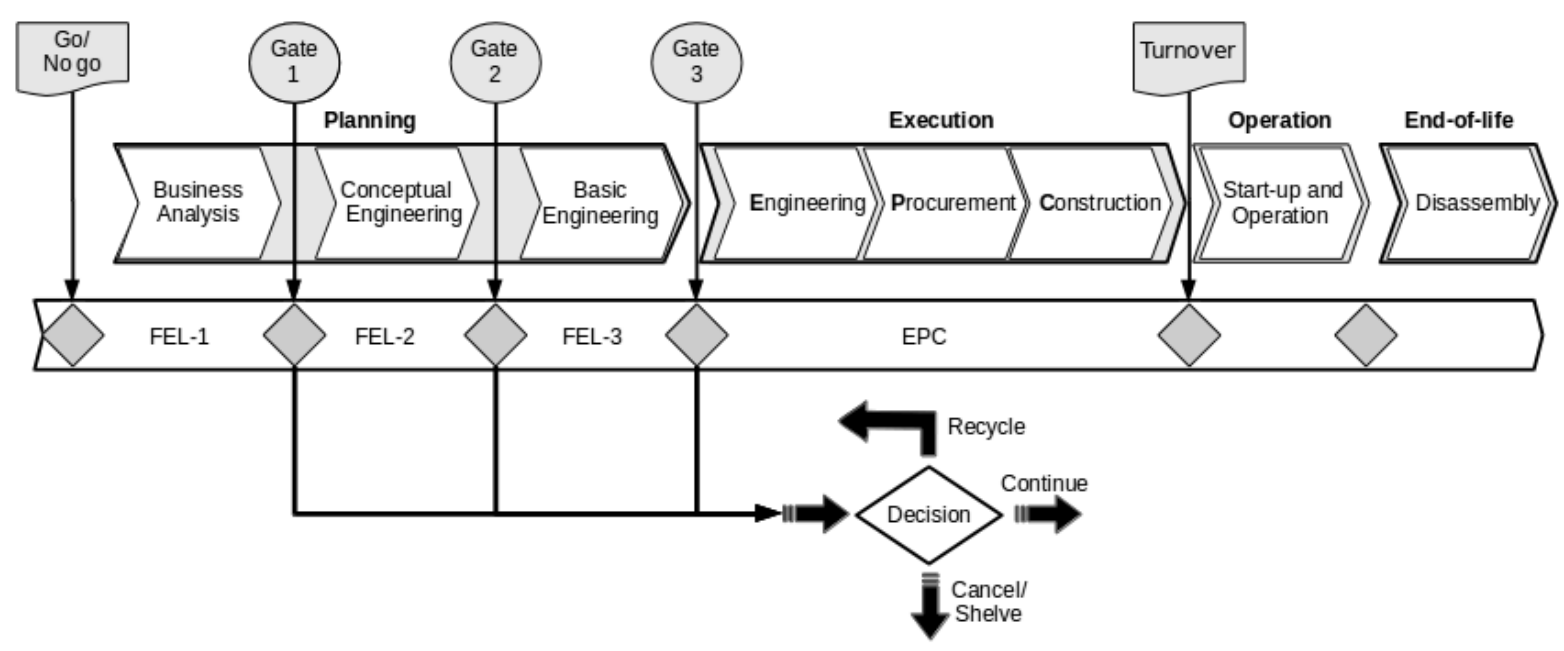

Figure 1 - Generic life cycle of projects with decision gates. Source: Adapted by authors from Merrow (2011).

Merrow (2011) presents that the FEL methodology consists of three phases: FEL-1 phase, which deals with business analysis - dedicated to developing the business case and decision of the viability of capital investment in the project. A key issue at this stage is to check whether the project in question is in line with the business strategy; FEL-2 phase, which addresses the conceptual engineering - is the phase of the scope selection and development of the conceptual design, where technical staff will make every installation diagrams, defining the entire project scope, and consequently improving cost estimates; and FEL-3 phase is the phase of basic engineering - involves the advancement of engineering to a level of detail that enables the advancement to the next stage without further changes.

Table 1 presents - for a specific case in a Brazilian mining company - the objectives and the main activities that must be developed in each of the phases of the FEL methodology.

Table 1 - Case of the FEL methodology

\begin{tabular}{l|ll}
\hline Phase Goals & Main Activities \\
\hline $\begin{array}{l}\text { Based on the analysis of } \\
\text { the attractiveness of the } \\
\text { business, develop and } \\
\begin{array}{l}\text { evaluate investment } \\
\text { opportunities, always } \\
\text { aligned with the } \\
\text { company's goals and } \\
\text { strategies. }\end{array}\end{array} \quad 3 \quad \begin{array}{l}\text { Identify business opportunities, define project guidelines and their drivers } \\
\text { for time, cost, etc. } \\
\text { Develop the business plan for the opportunity (business case), exploiting } \\
\text { to the maximum the identification and characterization of the set of } \\
\text { technical alternatives for the project }\end{array}$ \\
$\begin{array}{l}\text { FEL } \\
1\end{array}$ & $\begin{array}{l}\text { Select technology and determine permissible product specifications } \\
\text { Select the related alternatives, eliminating those that do not give } \\
\text { sustainability to the project, or that introduce fatal risks (quality, volume } \\
\text { of resources / reserves, technological, socio-environmental, political } \\
\text { aspects, etc.) }\end{array}$ \\
\hline $\begin{array}{l}\text { Develop: WBS; scope definition; detailed schedule; hiring plan; detailed } \\
\text { budget and team sizing }\end{array}$
\end{tabular}




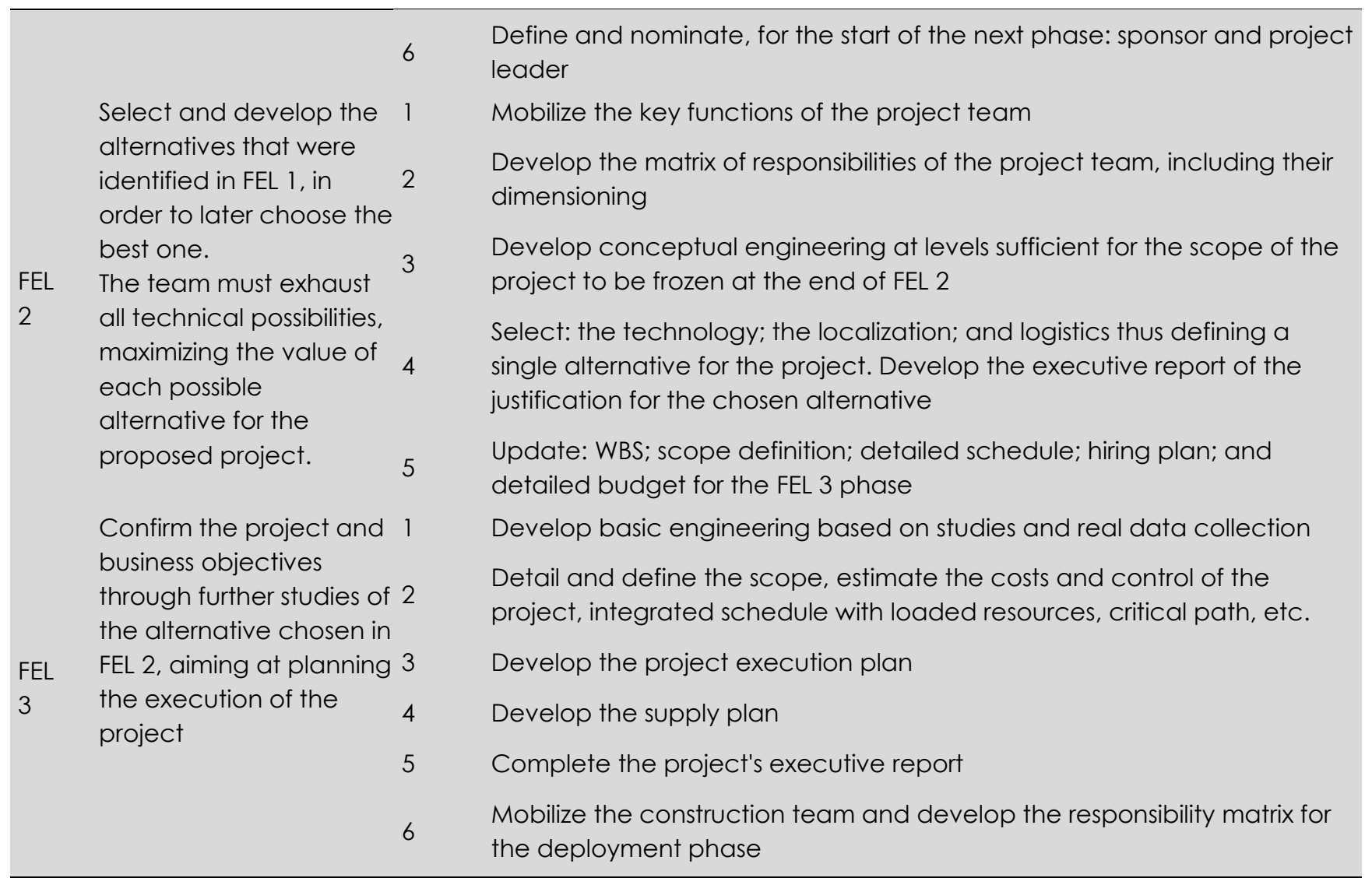

Source Adapted by authors from Vale (2011)

According to Figure 1, the passage between phases occurs through the decision process of the gates (gate process); in this process, all deliveries of the phase in question are evaluated and if they confirm strategic alignment and economic and financial viability, the project will proceed to the next phase; if not approved, new studies can be carried out for a new future analysis, or the project can be simply canceled / archived. Merrow (2011).

Upon completion of the phases of FEL - that is, the phase of project planning - comes phases of project implementation, known as EPC, also made up of three stages, namely: i) Engineering; ii) Procurement; and iii) Construction. The transition phase of the planning stages (FEL) to implement (EPC) is known as Front End Engineering Design (FEED) (Ramos, 2006).

One of the FEL-1 activities is the development of the business plan of opportunities (business case). The business case describes the rationale for the project in terms of value being added to the business as a result of its implementation. It should list the restrictions associated with the proposed development, the estimated budget and the alignment with the strategies established by the organization, may include qualitative benefits (intangible) and quantitative (tangible), cost estimates and time to break even, earnings expectations and additional opportunities; may submit the expected impact of actions on the cash flow and the methods and the reasoning used to quantify the benefits and costs (IIBA, 2011).

Specifically with regards to risk analysis technique, its purpose is to determine whether the initiative brings more risks that the organization is willing to tolerate. It focuses mainly on the solution viability risks that should be revisited throughout the project; the risks that should be considered: i) technical, that is, if the technology and suppliers can deliver the required functionality; ii) financial, whether costs will exceed levels that make the solution unviable or if potential benefits can be nullified; and iii) organizational and business changes (IIBA, 2011). 
Along the same lines, Kerzner (2011) states that good business cases identify the risks that the project should consider. For PMI (2013), the business case provides the necessary information from a business point of view, to determine whether the investment in the project is viable or not, that is, it is used for decision making on the part of senior management in a decision-making level higher than the project.

\section{Infrastructure projects}

According to Grimsey and Lewis (2002) investments in infrastructure should provide the basic services for the industry and society. They are the main inputs in an economy and essential to the economic activities and the country's growth. Normally, the activities considered as infrastructure investment include: i) energy (power generation and supply); ii) transport (roads, subway systems, bridges and tunnels); iii) water (sanitation, wastewater treatment and water); iv) telecommunication (phones); v) social infrastructure (hospitals, prisons, courts, museums, schools and government housing).

Some particularities of infrastructure projects compared to traditional investment projects are: i) the large amounts of capital involved; ii) the long periods of maturation; iii) cover services considered essential to society; and iv) low liquidity (Grimsey \& Lewis, 2002; Brandão \& Saraiva, 2007).

In Brazil, infrastructure services are provided by the public power or delegated to third parties; the delegation can happen between two different hiring schemes, namely: i) the specific scope contracts; and ii) concession contracts. Specific scope contracts are regulated by Law 8.666 / 93 (Tenders and Contracts Law). Already concessions may occur supported by Law 8.987 / 95 (the Common Concessions Law) or by Law 11.079 / 04 (Law on Public-Private Partnerships) (Marar, Aragon, \& Santos, 2004).

Millones (2010) presents an overview of the stages in the life of a development cycle in PPP mode, divided into four steps: i) the planning phase and exploitation that takes care of the structure of the partnership, the definition of the project scope and sharing risks among partners; ii) the design phase, where the project plan is modelled and the functional requirements and information are unified in design specifications; iii) the construction phase that includes the construction of facilities; and iv) the phase of operation and maintenance of the conveyor system.

An efficient transport system needs to predict its demand in order to align it to the infrastructure, supply the passengers with systems' information as well to reduce energy consumption and emissions, ensuring the maintenance of high standards of security (ANTP \& World Bank, 2012). As stated by Sismanidou and Tarradellas (2018), one of the main uncertainties in investments in infrastructure projects is if the future traffic demand will be sufficient to cover the cost of investments.

To forecast the future demand in such projects, the model Urban Transportation Model System (UTMS), also known as Transport Classic model; Four Stages model; and still Sequential model is a set of templates that are typically used in the transportation planning area (Laiza et al, 2008). This is based on relationships, medium and long term, transport to the socioeconomic characteristics of the region.

Gralla and Goentzel (2018) states that transportation planning process requires a lot of information from the transport systems, as well the variables associated with socio-economic issues in the region. This information can be obtained secondarily, usually by public and official research bodies. If the data is not available, it will be necessary to collect information at the study areas. To allow further analysis, the study should include: people characteristics (income, age, gender, profession, etc.), and data about the trip (time, frequency, reason, mode of transport used, etc.) (Campos, 2013).

The first step of the UTMS model is the generation of travel, estimating the amount of generated travel (produced and drawn) for each traffic area. From the total number of trips generated in each zone, there is the distribution among the other traffic areas, reaching a source array and travel destination. Further, for every travel assembly held between pairs of traffic areas it is estimated the amount of travel in the various modes. Finally, the allocation step, also considered as a balance analysis between supply and demand, it is the distribution of travel by mode of transport (Campos, 2013). With the departure of UTMS model - after 
the trips allocation step - studying the alternatives of transport modes (bus, subway, train, monorail, etc.) to be proposed in order to meet future demand in the region in question.

Although this model is quite widespread (Laiza et al, 2008), other prediction methods have been tested. Alekseev and Seixas (2009) have developed a neural model for passenger air transport demand forecast in Brazil getting better results than those obtained with the econometric model used at the time. Viglioni (2008) used five short-term demand forecasting techniques (short-term) for railway demand request, as follows: i) moving average; ii) exponential smoothing; iii) exponential smoothing with trending series (Holt method); iv) linear regression; v) artificial neural networks, and the best results were achieved with the technique of ANN. With a data sample of 3 years, technique has obtained the reduction of error, on average, $25 \%$, even without removing the components of the trend and seasonality of the series.

Thus, due to the relevance of demand forecast in the early planning stages of passenger transportation infrastructure projects, the frequent use of the UTMS model and the potential of ANN-based forecasting models, it is interesting to analyze the application of possibility a demand forecasting model based on ANN using as input variables of the UTMS model. Figure 2 illustrates the conceptual framework of the issue of this research, where the UTMS model input data will be applied to a neural model to train it, test it and validate it, generating passenger demand forecasting which could It is used in the study of economic and financial viability, serving as a tool for investment decision-making.

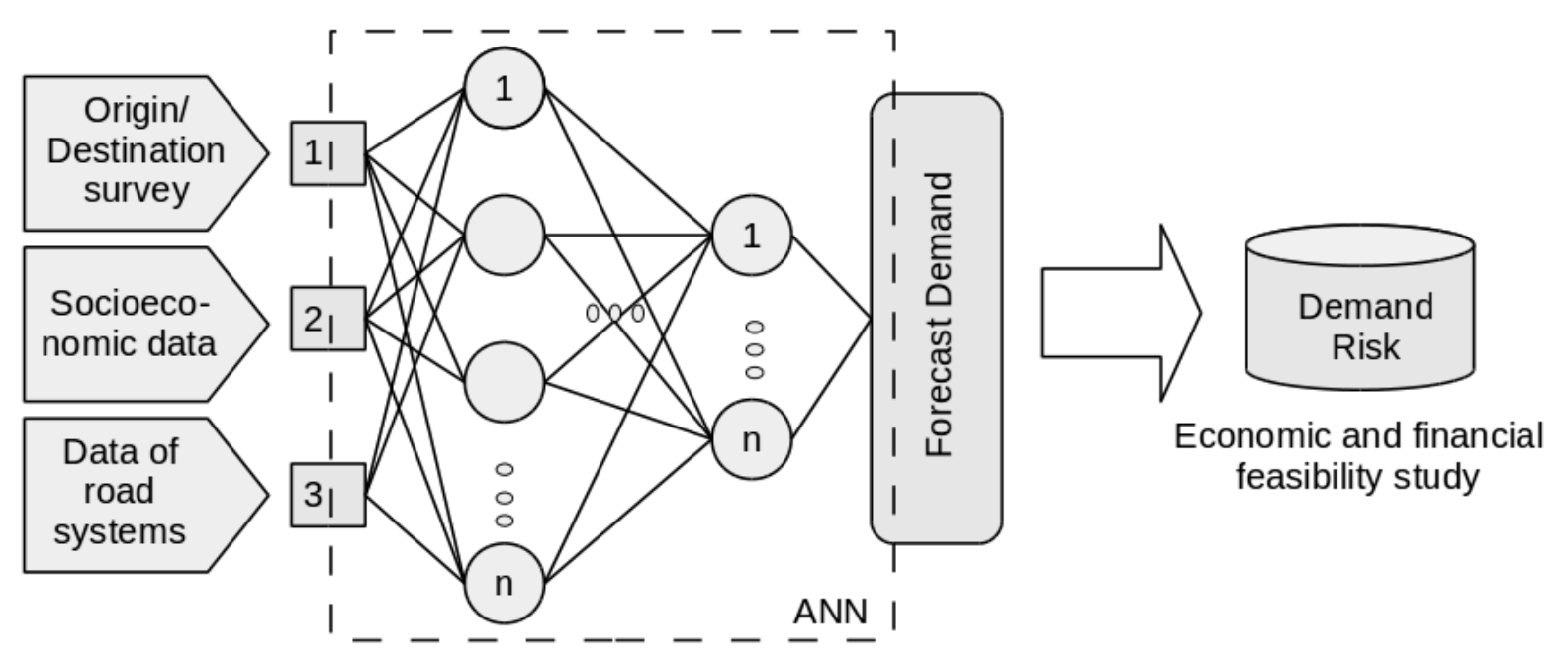

Figure 2 - Proposed Model. Source: Authors.

\section{Materials and methods}

The objective of this paper to propose a demand forecasting model for passenger transport ANN-based rail systems, using as input variables of the UTMS model. For it, a descriptive quantitative research on the type ex-post-facto was held.

The research group is formed by the subway stations in the city of São Paulo, operated by Metro-SP which has 61 stations divided into 4 lines and ViaQuatro, which operates 6 stations in one line, and by the metropolitan train stations, operated by CPTM, with 100 stations divided into 6 lines.

\section{Variables}

As for inputs of the neural model four independent variables were used based on the input variables of the UTMS model. All are from the Urban Mobility Search (UMS) Database in the Metropolitan Region of São Paulo (MRSP), 2012, always related to the traffic area in question; these being: the population; the school enrolment; the number of jobs; and per capita income. 
The dependent variable is passenger demand; their values were obtained from the basic passenger input data that has been requested from operators of transport systems considering the periods in which the UMS-MRSP survey of 2012 was conducted. Input data was requested from all the stations that are part of the research group.

\section{Data collection}

In this work, we have used secondary data sources. The independent variables were collected from the UMS-MRSP, held in 2012. The dependent variable - which is passenger demand - was collected in the passenger entry database of stations belonging to the research group. Research Origin/Destination (O/D) is performed by Metro every ten years; due to changes in 124 Metropolis displacement patterns during that period, a calibration survey is conducted 5 years after research $0 / D$, this benchmarking study was conducted in 2012 and was named UMS-MRSP 2012. This survey covered the entire metropolitan region of São Paulo and consisted of two surveys: i) the home where interviews were conducted with structured questionnaire in a sample of households selected by lot, investigating features of travel of residents on the business day prior research as well as socioeconomic characteristics (internal trips to MRSP); ii) the contour line, which are counts and interviews at access points to the highways MRSP thus investigating travel flows that enter, leave or cross the region (external trips to MRSP). The survey polled 8,115 households in 31 traffic areas. (Metro, 2013).

\section{Data analysis}

To analyse the data, the technique Artificial Neural Network (ANN) was used, following the procedures: a) pre-processing of data; b) the training, validation and network tests; and c) post-processing of the data. All the steps and procedures were performed in Scilab version 5.4.1 software, with the complement ANN Toolbox 0.4.2.5, a complementary program that enables Scilab to work with RNA, developed by Hristev (1998).

During pre-processing, the data were normalized as proposed by Lourencetti (2011). Then the data set of traffic areas involved were divided randomly into three different groups, namely: training group, equal to $50 \%$ of the data set of tests, equal to $25 \%$ of the data and group validation, formed by the rest of the data. Table 2 shows the standardized data set. The original data used and scripts can be accessed at https://github.com/vsvasconcelos/mestrado.

Regarding the number of definitions of hidden layers and the number of neurons in each of these layers, Kovács (2002) presents a review of the Kolmogorov theorem adapted to ANN, stating that an ANN with three layers - that is, a layer of input, an output and a hidden (occult) - can accurately implement a continuous function. However, in order to provide greater comparisons were proposed types with one or two hidden layers. Regarding the number of neurons in the hidden layer, there are some heuristic rules that can be used as a starting point for determining the number of neurons, that when the ANN has only one hidden layer (Freiman, 2004). Hence, the proposed neural model features four independent variables, based on these methodologies, trained, tested and validated 12 ANN architectures, enabling its comparison to identify which ones have the best results.

All nets used are of the multilayer perceptron type (MLP), as their ability to hidden layer with an approximate any continuous function; and two hidden layers approximate any mathematical function. (Braga, Carvalho, \& Ludermir, 2000). The activation function was chosen the sigmoidal, since this function provides an output between 0 and 1 .

Regarding the second stage of the review process - training, validation and network tests - the learning algorithm used for training of all ANN was the backpropagation (Braga et al., 2000). Training took place in two phases, known as forward and backward phase. Two important parameters of the learning algorithm are: i) the learning rate, which represents the softness of updating the network weights; and ii) 
the term momentum that has the function, if necessary, of accelerating the training of the network. In this work, we were tested for all networks the following values for the learning rate: 0.01 ; 0.5 ; and 0.9 . As for the expiry date, the following values were tested: 0.5; and 0.9. As stopping criteria for training error tolerance and the number of times have been adopted. The tolerance of the adopted error was 0.0001 , and the number of iterations was 10,000 times. For all ANN architectures defined, the three sets of data were applied by checking what the best result achieved, thus identifying the best architecture, which was the one with the lowest mean squared error (MSE) at validation.

During the post-processing of the data, it analysed the relevance of each model input variable using the method proposed by Garson (Garson, 1991). Having identified the relevant variables, a new network has been trained, tested and validated considering only these variables as input.

Table 2 - Standardized data set

\begin{tabular}{|c|c|c|c|c|c|}
\hline Zone & Population & School enrollment & Jobs & Income & Passenger demand \\
\hline 1 & 0,267 & 0,593 & 0,900 & 0,362 & 0,900 \\
\hline 2 & 0,336 & 0,310 & 0,185 & 0,185 & 0,116 \\
\hline 4 & 0,485 & 0,418 & 0,385 & 0,223 & 0,200 \\
\hline 5 & 0,127 & 0,151 & 0,184 & 0,392 & 0,149 \\
\hline 6 & 0,290 & 0,201 & 0,145 & 0,178 & 0,133 \\
\hline 7 & 0,203 & 0,259 & 0,217 & 0,247 & 0,170 \\
\hline 8 & 0,192 & 0,162 & 0,100 & 0,209 & 0,152 \\
\hline 9 & 0,260 & 0,232 & 0,163 & 0,201 & 0,130 \\
\hline 10 & 0,397 & 0,431 & 0,187 & 0,100 & 0,120 \\
\hline 11 & 0,225 & 0,208 & 0,125 & 0,148 & 0,163 \\
\hline 13 & 0,268 & 0,234 & 0,107 & 0,109 & 0,124 \\
\hline 14 & 0,100 & 0,100 & 0,349 & 0,891 & 0,302 \\
\hline 15 & 0,145 & 0,147 & 0,440 & 0,900 & 0,100 \\
\hline 16 & 0,154 & 0,199 & 0,255 & 0,484 & 0,234 \\
\hline 17 & 0,259 & 0,224 & 0,186 & 0,216 & 0,147 \\
\hline 18 & 0,435 & 0,478 & 0,420 & 0,187 & 0,214 \\
\hline 19 & 0,398 & 0,434 & 0,202 & 0,143 & 0,160 \\
\hline 20 & 0,452 & 0,413 & 0,202 & 0,119 & 0,168 \\
\hline 21 & 0,279 & 0,256 & 0,210 & 0,191 & 0,132 \\
\hline 22 & 0,187 & 0,203 & 0,184 & 0,241 & 0,181 \\
\hline 23 & 0,161 & 0,332 & 0,366 & 0,482 & 0,316 \\
\hline 24 & 0,292 & 0,240 & 0,149 & 0,121 & 0,130 \\
\hline 26 & 0,703 & 0,711 & 0,408 & 0,112 & 0,163 \\
\hline 27 & 0,736 & 0,763 & 0,502 & 0,178 & 0,179 \\
\hline 31 & 0,900 & 0,900 & 0,617 & 0,147 & 0,182 \\
\hline
\end{tabular}

Source: Authors.

\section{Results}

As detailed in section Materials and Methods, first, the data are pre-processed, which is a step that involves normalization and reassembly of data. Then, they three sets of data are generated: data 1; data 2; and 3 data, which are the result of reunification in random order of standard data. They are shown in Table 3 , where for each set are presented data traffic zones which have been used for training, testing and validation of the neural models. Regardless of ANN architectures proposed in this paper, the data sets used in steps of training, validation and testing were always the same ones listed in Table 3. 
Table 3 - Data groups of training, test and validation.

\begin{tabular}{|c|c|c|c|}
\hline & \multicolumn{3}{|l|}{ Traffic Zone } \\
\hline & Data 1 & Data 2 & Data 3 \\
\hline Training & $\begin{array}{l}4,11,7,10,16,15,24,5,8 \\
31,17 \text { e } 6\end{array}$ & $\begin{array}{l}9,14,20,24,2,21,16,5,18 \\
8,31 \text { e } 17\end{array}$ & $\begin{array}{l}13,24,2,6,17,9,18,26,16,7, \\
15 \text { e } 27\end{array}$ \\
\hline Testing & $2,13,19,18,22$ e 14 & $7,1,26,13,10$ e 11 & $8,23,1,10,20,14$ \\
\hline Validation & $26,1,20,27,9,23$ e 21 & $4,15,22,27,23,19$ e 6 & $19,31,22,4,5,21$ e 11 \\
\hline
\end{tabular}

Source: Authors.

As can be seen in Table 3, data from 12 traffic zones were used for training the neural networks, 5 for tests and 5 for validation. The order of the data established in this table has always been respected for the training, testing and validation of the 12 proposed ANN architectures. Just as an example, traffic zone 4 , which is the first training data in the Data 1 data set, as shown in Table 3, consists of the following stations on Line 1-Blue of the Metro: Tietê, Carandiru, Santana, Jardim SP , Parada Inglesa and Tucuruvi, which together have a total entrance of 239,172 passengers / day.

For each of the 12 ANN proposed architectures, steps training, testing and validation were performed by changing the combination of the learning rate and momentum and applying the data set of Chart 1 . Five combinations were adopted for the learning rate / time and three sets of data. Thus, for each ANN, architecture training procedures were performed, testing and validation 15 times; totalizing, for 12 architectures, 180 procedures. For each, we calculated the values of the model validation phase, i.e. the output of the neural model. With these values we estimated the correlation coefficient ( $\mathrm{r}$ ) and coefficient of determination $\left(\mathrm{R}^{2}\right)$, the graphics of error depending on the training times and test the network, and scatter plots of the real values obtained in the databases operators of MRSP systems, with predicted values at the output of neural models.

\section{AnN ARChitecture analysis}

Table 4 presents a summary sorted in ascending order by MSE percentage, with the best results obtained for each of architectures of the settings made. It is observed that the best architecture, among the proposals in this paper, was architecture 12 (Arq-12) with the training rate and time equal to 0.9 , using the data set 3 , getting a percentage of average square error $0.045 \%$. At the other extreme is the architecture 04 (Arq-04), which performed at worst, with a square error of $0.543 \%$.

Table 4 - Summary of the best results ordered by MSE\%

\begin{tabular}{|c|c|c|c|c|c|c|c|c|}
\hline \multicolumn{2}{|c|}{ Architecture } & $\begin{array}{l}\text { Training rate/ } \\
\text { Momentum }\end{array}$ & $\begin{array}{l}\text { Data } \\
\text { Sets }\end{array}$ & $\begin{array}{l}\text { Time [s] } \\
\text { Training }\end{array}$ & Testing & $\begin{array}{l}\text { MES\% } \\
\text { Validation }\end{array}$ & \multicolumn{2}{|l|}{ Coefficient } \\
\hline Arq-12 & {$[4,5,10,1]$} & $0.9 / 0.9$ & Data 3 & 62.231 & 35.655 & 0.045 & 0.478 & 0.228 \\
\hline Arq-06 & {$[4,9,5,1]$} & $0.5 / 0.5$ & Data 3 & 63.983 & 36.438 & 0.050 & 0.288 & 0.083 \\
\hline Arq-05 & {$[4,3,2,1]$} & $0.9 / 0.5$ & Data 3 & 67.761 & 36.673 & 0.053 & 0.209 & 0.043 \\
\hline Arq-09 & {$[4,3,6,1]$} & $0.5 / 0.9$ & Data 3 & 63.387 & 36.257 & 0.053 & 0.480 & 0.230 \\
\hline Arq-07 & {$[4,2,1,1]$} & $0.9 / 0.5$ & Data 3 & 61.079 & 35.006 & 0.057 & 0.145 & 0.021 \\
\hline Arq-11 & {$[4,2,4,1]$} & $0.9 / 0.5$ & Data 3 & 63.052 & 36.037 & 0.061 & 0.031 & 0.001 \\
\hline Arq-08 & {$[4,5,3,1]$} & $0.5 / 0.5$ & Data 3 & 143.882 & 35.634 & 0.064 & 0.419 & 0.175 \\
\hline Arq-03 & {$[4,2,1]$} & $0.9 / 0.9$ & Data 3 & 48.511 & 28.976 & 0.078 & 0.290 & 0.084 \\
\hline Arq-10 & {$[4,9,18,1]$} & $0.5 / 0.5$ & Data 3 & 67.105 & 38.176 & 0.109 & 0.491 & 0.241 \\
\hline Arq-02 & {$[4,9,1]$} & $0.5 / 0.9$ & Data 3 & 54.290 & 38.148 & 0.138 & 0.605 & 0.366 \\
\hline Arq-01 & {$[4,3,1]$} & $0.5 / 0.9$ & Data 3 & 57.853 & 39.561 & 0.189 & 0.459 & 0.210 \\
\hline Arq-04 & {$[4,5,1]$} & $0.5 / 0.5$ & Data 3 & 49.475 & 29.454 & 0.543 & 0.052 & 0.003 \\
\hline
\end{tabular}

Source: Authors.

After analysing the architectures in order to give greater validity to the results obtained, we used the Garson method, which allows an analysis of relevance of each of the input variables of a neural model. For this it used the architecture 03 (Arq-03) as the architecture that performed better presenting only one 
hidden layer. Figure 3 shows the ANN proposal in the Arq-03, with details of the weights of each of the connections and the bias of the two neurons in the hidden layer and output.

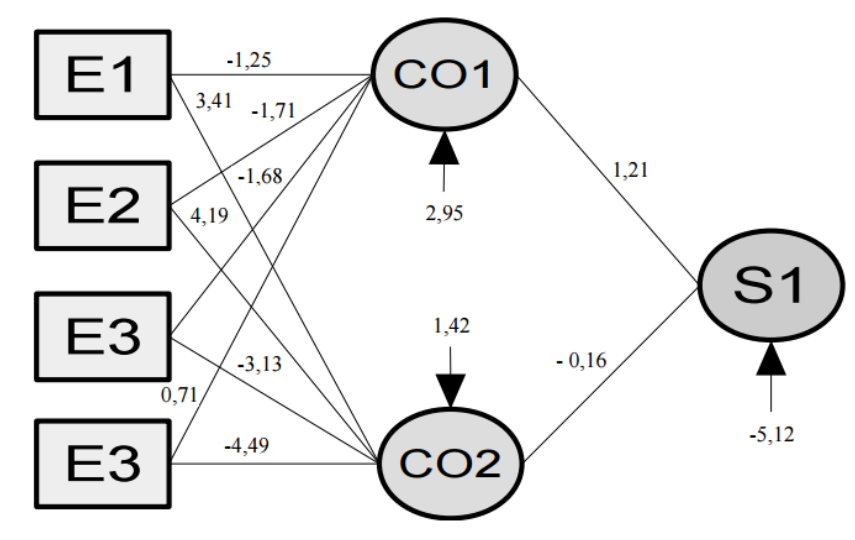

Figure 3 - Architecture 3 with weights and bias. Source: Authors.

The first step is to calculate the contribution of each entry in the output of the neural network, always passing by hidden neurons. The relative importance of each of the ANN inputs is obtained by the sum of the contribution of the division on each entry by the total sum of the relative contributions. Following this methodology, you can find the following relative contribution: School Enrollment (29.74\%), Jobs (25.94\%), population $(22.88 \%)$ and income per capita $(21.44 \%)$.

To test the influence of the less relevant variables in the neural model results, two tests were performed. Initially only less relevant model should be excluded from the variable, where the per capita income; and then deleted the two less relevant variables in the model, leaving only the variables school enrollment and employment. In both the ANN tests have been trained in the best configuration already obtained for the Arq-03. The percentage MSE obtained with these new architectures were 0.086 for Arq-3.1 and 3.662 for Arq-3.2. As shown in Table 4, the percentage obtained by MSE Arq-03 was 0.078\%; so, compared to the results, the Arq-3.1 and Arq-3.2 architectures had worse results, approximately 10\% and $4595 \%$, respectively, demonstrating that the complete model with four independent variables, population, school enrollment, Jobs and income per capita, is the most appropriate.

These results demonstrate the importance of these variables for forecasting transport demand and are in line with other research. According to Marques and Bracarense (2016), public transport is deeply affected by the distribution of the population and the number of jobs. The same is defended by Geurs \& van Wee (2004), when they stated that transport planning should assess the accessibility of locations at the macro level, taking into account the number of jobs. For Campos (2013), in the travel generation process, the growth factor method uses aggregated data on population, income and vehicle ownership.

Regarding the population's income, Carvalho \& Pereira (2011) analyzed its effect, together with the tariff, on the transport system of nine Brazilian capitals. Albalate \& Bel (2010), when analyzing the supply and demand for transport in European cities using income, costs and characteristics of cities, time spent traveling, as variables, identified that, for the model, income, demographic density and other factors continue to have an influence both in supply and demand.

In terms of the number of school enrollments offered, Lopes Filho (2003) proved to be a significant variable when forecasting demand for buses in the city of Fortaleza in a linear model of travel generation. Silva (2019), when analyzing the determining factors for the change in daily trips in São Paulo since 2012, lists the increase in formal jobs and school enrollments. In addition, the research by Murça \& Müller (2014) on the demand for urban public transport in the city of Salvador recommend the use of the number of school enrollments, among other variables, in future studies of forecasting the demand for transport. 


\section{Final considerations}

This study aimed to propose a demand forecasting model based on ANN for use in the studies of economic and financial viability of passenger rail projects. The proposed architectures were implemented and validated in SciLab tool with the ANN toolbox.

The identification of the input variables (independent variables) that explain the passenger demand was performed by analysing the results of UMS-MRSP 2012, where it was evidenced that the variables: Population the traffic zone; School enrolment; Number of jobs; and per capita income, could explain to user demand in metro stations.

This work results in managerial and academic implications. For managers, it provides a demand forecast model, with which it would be possible to estimate the capital investment costs (CAPEX) and operation and maintenance (OPEX), and its operating income, and thus to set the flow project cash. From this, using some approach of analysis, such as discounted cash flow, the Real Options Theory, the Creation of Shareholder Value, among others, to arrive at indicators that can serve as a tool in decision making Investment in the project is still at the project design stage. For the private partner this can be a valuable knowledge for making capital investment decisions on a passenger transportation infrastructure project on track, especially in the form Public-Private Partnership (PPP), and also in Public Expressions of Interest (MIP), where the private sector identifies an opportunity and propose a project to the public sector.

For academia, it contributes to the management of passenger transport enterprises projects on track, specifically in FEL-1 phase of FEL methodology, providing a tool in the study of economic and financial feasibility of the project with innovative methodology, which brings robustness to process, assisting in decision making.

Among the limitations of the research is the process of data collection that featured 31 traffic areas of the 460 used in Origin-Destination survey conducted by Metro in 2007. For future research it is suggested retrace the steps of training, testing and validation the architectures proposed in this work, now using the full OD survey data and apply the neural model proposed in other regions which have a subway-railroad system in order to verify the results of predictions carried out by validating them in other contexts.

\section{References}

Albalate, D., \& Bel, G. (2010). What shapes local public transportation in Europe? Economics, mobility, institutions, and geography. Transportation Research Part E: Logistics and Transportation Review, (46)5, 775-790.

Alekseev, K. P. G., Seixas, J. M. (2009). A multivariate neural forecasting modeling for air transport - preprocessed by decomposition: a Brazilian application. Journal of Air Transport Management, 15(5), 212-216.

Alvim, B. G., Bilt, K. V. de, \& Darido, G. B. (2010). Evolução e Tendências na Implantação e Financiamento dos Sistemas de Transporte Público Sobre Trilhos (p. 51). São Paulo: Associação dos Engenheiros e Arquitetos de Metrô - AEAMESP.

ANTP, Associação Nacional de Transporte Público, \& World Bank (Orgs.). (2012). Sistemas Inteligentes de Transportes.

Barua, L., Zou, B., \& Zhou, Y. (2020). Machine learning for international freight transportation management: a comprehensive review. Research in Transportation Business \& Management, 100453.

Bonomi, C. A., \& Malvessi, O. (2008). Project Finance no Brasil: Fundamentos e estudo de casos. Atlas.

Braga, A. de P., Carvalho, A., \& Ludermir, T. B. (2000). Redes neurais artificiais: teoria e aplicações. Rio de Janeiro: Livros Técnicos e Científicos.

Brandão, L. E. T., \& Saraiva, E. C. G. (2007). Risco privado em infra-estrutura pública: uma análise quantitativa de risco como ferramenta de modelagem de contratos. RAP-Revista de Administração Pública. Rio de Janeiro, 41(6), $1035-67$.

Campos, V. B. G. (2013). Planejamento de Transportes: Conceitos e Modelos. Rio de Janeiro: Interciência.

Carvalho, C. H. R., \& Pereira, R. H. M. (2011). Efeitos da variação da tarifa e da renda da população sobre a demanda de transporte público coletivo urbano no Brasil. Brasília: IPEA. 
Cooper, R. G. (2008). Perspective: The Stage-Gate ${ }^{\circledR}$ Idea-to-Launch Process-Update, What's New, and NexGen Systems*. Journal of Product Innovation Management, 25(3), 213-232.

Dreyer, H. C., Kiil, K., Dukovska-Popovska, I. ,\& Kaipia, R. (2018). Proposals for enhancing tactical planning in grocery retailing with S\&OP. International Journal of Physical Distribution \& Logistics Management, 48(2), 114-138.

Fedorenko, R. (2019). Modern issues of development of the customs and logistics infrastructure of the international NorthSouth transport corridor. Contributions to Economics, 1, 63-77.

Flyvbjerg, B. (2013). Quality control and due diligence in project management: Getting decisions right by taking the outside view. International Journal of Project Management, 31(5), 760-774.

Flyvbjerg, B., Bruzelius, N., \& Rothengatter, W. (2003). Megaprojects and Risk: An Anatomy of Ambition. Cambridge, UK: Cambridge University Press.

Fouto, N. M. M. D., de Angelo, C. F., Zwicker, R., \& Luppe, M. R. (2011). Séries temporais e redes neurais: uma análise comparativa de técnicas na previsão de vendas do varejo brasileiro. BBR-Brazilian Business Review, 8(2), 1-21.

Freiman, J. P. (2004). Utilização de Redes Neurais Artificiais na Previsão de Indicadores Financeiros para Avaliação Econômica de Negócios em Situação de Risco (Dissertação de mestrado). Universidade Federal de Itajubá, Itajubá.

Garson, G. D. (1991). Interpreting neural network connection weights. AI Expert, April, 47-51.

Geurs, K. T., \& Van Wee, B. (2004). Accessibility Evaluation of Land-use and Transport Strategies: Review and Research Directions. Journal of Transport Geography, 12(2), 127-140.

Ghisolfi, V., Ribeiro, G. M., Chaves, G., Orrico Filho, R. D., Hoffmann, I., \& Perim, L. R. (2019). Evaluating impacts of overweight in road freight transportation: a case study in Brazil with system dynamics. Sustainability, 11(11), 3128

Graham, J., \& Harvey, C. (2002). How do CFOs make capital budgeting and capital structure decisions? Journal of Applied Corporate Finance, 15(1), 8-23.

Gralla, E., \& Goentzel, J. (2018). Humanitarian transportation planning: Evaluation of practice-based heuristics and recommendations for improvement. European Journal of Operational Research, 269(2), 436-450.

Grimsey, D., \& Lewis, M. K. (2002). Evaluating the risks of public private partnerships for infrastructure projects. International Journal of Project Management, 20(2), 107-118.

Hair JR, J. F., Black, W. R., Babin, B. J., \& Anderson, R. E. (2010). Multivariate Data Analysis (7th ed.). Upper Saddle River, NJ, Prentice Hall.

Hassan, L. H., Mahmassani, H. S., \& Chen, Y. (2020). Reinforcement learning framework for freight demand forecasting to support operational planning decisions. Transportation Research Part E: Logistics and Transportation Review, 137, 101926.

Hristev, R. M. (1998). The ANN book (Vol. 71).

IIBA. (2011). Um guia para o Corpo de Conhecimento de Análise de Negócios (TM) (Guia BABOK®). IIBA.

Kerzner, H. (2011). GERENCIAMENTO DE PROJETOS - Uma Abordagem Sistêmica para Planejamento, Programação e Controle. EDGARD BLUCHER.

Kovács, Z. L. (2002). Redes Neurais Artificiais. São Paulo: Editora Livraria da Física.

Krüger, N. A. (2012). Estimating traffic demand risk-A multiscale analysis. Transportation Research Part A: Policy and Practice, 46(10), 1741-1751.

Laiza, M. C. de M., Duarte, E. J., da Silva, C. V. G., Rubira, J. A. de C., \& Bueno, J. de F. (2008). Os estudos de previsão de demanda no Metrô SP. Engenharia, 587, 122-125.

Leurent, F. (2011). Transport capacity constraints on the mass transit system: a systemic analysis. European Transport Research Review, 3(1), 11-21.

Lopes Filho, J. I. O. (2003) Pós-avaliação da previsão de demanda por transportes no município de Fortaleza. (Dissertação de Mestrado). Universidade Federal do Ceará, Fortaleza.

Lourencetti, F. H. (2011). Estudo da reprodução do comportamento hidráulico de sistemas de abastecimento de água via redes neurais artificiais (RNAs). (Tese de Doutorado). Universidade de São Paulo, São Paulo. 
Marar, J. R., Aragão, J. J. G., \& Santos, E. M. (2004). Licitação para contratação de parcerias público-privadas em infraestrutura de transportes no Brasil. In ANPET_CONGRESSO DE PESQUISA E ENSINO EM TRANSPORTES (Vol. 18, p. 13931404). Florianópolis.

Marques, S.F., \& Bracarense, L. S. F. P. (2016). A influência da forma urbana na viabilidade financeira do transporte público por ônibus em cidades médias. In ANPET_CONGRESSO DE PESQUISA E ENSINO EM TRANSPORTES. Rio de Janeiro.

Merrow, E. W. (2011). Industrial megaprojects: concepts, strategies, and practices for success. New Jersey: John Wiley \& Sons.

Millones, G. M. (2010). Breaking Down Factors of Public-Private Partnership in Urban Rail: Experience from Latin American Cases (Dissertação de mestrado). Delft University of Technology, Delft, Netherlands.

Murça, M. C. R, \& Müller, C. (2014). Transporte coletivo urbano: uma análise de demanda para a cidade de Salvador. Journal of Transport Literature, 8(1), 265-284.

PMI. (2013). A Guide to the Project Management Body of Knowledge: PMBOK Guide (5º ed). Pennsylvania: Project Management Institute, Incorporated.

Ramos, R. (2006). Gerenciamento de projetos: ênfase na indústria de petróleo. Rio de Janeiro: Interciência.

Ribeiro, R. L. O., do Valle, A. B., Soares, C. A. P., \& Santos, J. A. N. dos. (2013). From idea to benefit: project portfolio management using front end loading, the standard for portfolio management and PRINCE2. International Journal of Management, 4(5), 60-68.

Sales, O. P., \& Junior, O. C. (2011). O Modelo Stage Gate dentro do Processo de Desenvolvimento de um Produto-Uma Análise comparativa com o desenvolvimento de um produto de uma empresa de telecomunicações. In CBGDP - CONGRESSO BRASILEIRO DE GESTÃO DE DESENVOLVIMENTO DE PRODUTO. Porto Alegre.

Shenhar, A. J., \& Dvir, D. (2010). Reinventando gerenciamento de projetos - A abordagem diamante ao crescimento e inovação bem-sucedidos. São Paulo: Harvard Business School Press - M. Books.

Silva, R.B. (2019). Os constrangimentos da mobilidade na metrópole de São Paulo. Revista Transporte Y Territorio, 1, 165189.

Sismanidou A, Tarradellas J. (2018). Traffic demand forecasting and flexible planning in airport capacity expansions: lessons from the MadridBarajas new terminal area master plan. Case Studies on Transport Policy, 5(2), 188-199.

Vale. (2011). Metodologia FEL. Rio de Janeiro: Vale S.A.

van Engelen, M., Cats, O., Post, H., \& Aardal, K. (2018). Enhancing flexible transport services with demand-anticipatory insertion heuristics. Transportation Research Part E: Logistics and Transportation Review, 110, 110-121

Vasconcelos, V.S. (2015). Previsão de demanda na fase de planejamento antecipado de projetos de transporte de passageiros: uma abordagem por redes neurais artificiais. Dissertação (Mestrado em Administração). Universidade Nove de Julho, São Paulo.

Vasconcelos, V. S., Silva, F. Q., Rovai, R. L., \& Rached, C. D. A. (2019). Identification of the main risk factors in infrastructure projects of transporting people on rail by public-private partnerships. International Journal of Entrepreneurship, 23, 1-17.

Viglioni, G. M. C. (2008). Comparação entre redes neurais e técnicas clássicas para previsão de demanda de transporte ferroviário. Revista de Inteligência Computacional Aplicada (RICA), (1).

Xu, S., Chan, H. K., \& Zhang, T. (2019). Forecasting the demand of the aviation industry using hybrid time series SARIMASVR approach. Transportation Research Part E: Logistics and Transportation Review, 122, 169-180.

Editor: Fabio Duarte

Received: May $8^{\text {th }}, 2020$

Approved: Feb. 9th, 2021 